\title{
COLABORAM NESTE NÚMERO
}

Estanislau Fischlowitz - Economista, especializado em assuntos de economia de trabalho e politica social. Na Polônia, seu pais de origem, ocupou posições dirigentes no Ministério do Trabalho e Assistência Social. Como Ministro do Govêrno de Varsóvia foi responsável pela conclusão de 25 tratados com 12 países Desde 1940 radicado no Brasil e naturalizado «por serviços relevantes prestados ao país». Assistente Técnico contratado pelo D.A.S.P. (1941-943). Perito das Nações Unidas (B.I.T.), encarregado das missões de assistência técn'ca em 1954, 1955 e 1956, aos países da Ásia e América Central. Professor da Universidade Internacional de Estudos Sociais em Roma. Professor dos Cursos da Fundação Getúlio Vargas e do I.S.O.P. Assistente Técnico do S.E.S.I. (Departamento Nacional). Em 1953, presidiu a Conferência Interamericana de Mão de Obras (Lima). Relator de várias convienções internaciona's de trabalho. Participou de 35 conferências internacionais. Autor de numerosos estudos sócio-econômicos e administrativos. Exerce desde 1952 as funções de Assessor Técnico do Ministério do Trabalho, Indústria e Comércio.

Renato Travassos - Jornalista militante. Inspetor de várias Faculdades. Ex-Técnico de Educação do Ministério da Educação e Cultura. Presentemente Redator do Ministério da Justiça e Negócios In teriores, lotado na Agência Nacional. Autor de vários livros.

MARcíl1o VAZ TorRes - Espec alista em questões de Arquivistica; autor de d ferentes obras a respeito do assunto, algumas das quais já publicadas na Revistía do Serviço Público.

Calo Tácrto - Ex-Consultor Jurícico do D.A.S.P. Procurador do I.A.P.C.: Consultor Juridico do M.T.I.C.; Professor da U.D.F., Professor de Direito dos Cursos de Administração do D.A.S.P.;
Membro do Instituto Internacional de Ciências Administrativas e da Associação Brasileira de Direito Público. Tem representado o Brasil em diferentes congressos internacionais.

Francis Violich - Professor de Planejamento Urbano, Departamento de Planejamento Urbano e Regional, Universidade da California, Berkely. U.S.A.

VASCo RiBeiro DA Costa - Capitão do Exér cito servindo, presentemente, na Escola de Comando e Estado Maior do Exército. Economista pela Faculdade de Ciên. cias Politicas e Econômicas do Rio de Janeiro. Autor de «Considerações e Idéias sôbre o problema econômico nacional», trabalho editado pelo Serviço de Documentação do D.A.S.P. Autor de vários trabalhos publicados nas Revistas «Defesa Nacional» e «Clube Militar».

JAIr Tovar - Procurador Adjunto da Fazenda Pública; ex-Deputado Federal do Estado do Espirito Santo; ex-Consultor Juridico do Ministér o da Agricultura; exDiretor-Geral do D.A.S.P. (1954-55).

Carlos Gonçalo amaral - Assistente de Administração do D.A.S.P.; Advogado militante; ex-Assessor da Divisão de Seleção e Aperfeiçoamento do D.A.S.P.; aprosado em concurso para Assistente Jurídico e Juiz do Trabalho. Autor das seguintes obras: «Do concurso para provimento em cargo de carreira» e «Considerações sôbre o processo administrati. vo», publicados respectivamente, nesta Revista em outubro de 1950, e na Revista dos Bancários, números 1,2 e 3 .

Nelson Nascimento Santos - Engenheiro do Q.P. do Ministério da Fazenda, lotado no Serviço do Patrimônio da União. Possui trabalhos sôbre avaliações de terrenos de imóve's de novo processo do cálculo de áreas levantadas topogràficamente, publicados em doze revistas do Clube de Engenharia do Rio de Janeiro. 